\title{
Mechanisms of Stem Cell Therapy in Spinal Cord Injuries
}

\author{
Munehisa Shinozaki $^{1}\left(\mathbb{D}\right.$, Narihito Nagoshi $^{2}$, Masaya Nakamura $^{2} \mathbb{D}$ and Hideyuki Okano ${ }^{1, *(D)}$ \\ 1 Department of Physiology, Keio University School of Medicine, 35 Shinanomachi, Shinjuku-ku, \\ Tokyo 160-8582, Japan; shinozaki.mu@gmail.com \\ 2 Department of Orthopedic Surgery, Keio University School of Medicine, 35 Shinanomachi, Shinjuku-ku, \\ Tokyo 160-8582, Japan; nagoshi@keio.jp (N.N.); masa@keio.jp (M.N.) \\ * Correspondence: hidokano@a2.keio.jp
}

Citation: Shinozaki, M.; Nagoshi, N.; Nakamura, M.; Okano, H.

Mechanisms of Stem Cell Therapy in Spinal Cord Injuries. Cells 2021, 10, 2676. https://doi.org/10.3390/ cells10102676

Academic Editors: Kee D. Kim and Julius O. Ebinu

Received: 7 September 2021

Accepted: 4 October 2021

Published: 6 October 2021

Publisher's Note: MDPI stays neutral with regard to jurisdictional claims in published maps and institutional affiliations.

Copyright: (c) 2021 by the authors. Licensee MDPI, Basel, Switzerland. This article is an open access article distributed under the terms and conditions of the Creative Commons Attribution (CC BY) license (https:// creativecommons.org/licenses/by/ $4.0 /)$.

\begin{abstract}
Every year, 0.93 million people worldwide suffer from spinal cord injury (SCI) with irretrievable sequelae. Rehabilitation, currently the only available treatment, does not restore damaged tissues; therefore, the functional recovery of patients remains limited. The pathophysiology of spinal cord injuries is heterogeneous, implying that potential therapeutic targets differ depending on the time of injury onset, the degree of injury, or the spinal level of injury. In recent years, despite a significant number of clinical trials based on various types of stem cells, these aspects of injury have not been effectively considered, resulting in difficult outcomes of trials. In a specialty such as cancerology, precision medicine based on a patient's characteristics has brought indisputable therapeutic advances. The objective of the present review is to promote the development of precision medicine in the field of SCI. Here, we first describe the multifaceted pathophysiology of SCI, with the temporal changes after injury, the characteristics of the chronic phase, and the subtypes of complete injury. We then detail the appropriate targets and related mechanisms of the different types of stem cell therapy for each pathological condition. Finally, we highlight the great potential of stem cell therapy in cervical SCI.
\end{abstract}

Keywords: spinal cord injury; stem cell therapy; target of clinical trial; translational research; activities of daily living; complete injury

\section{Introduction}

Spinal cord injury (SCI) affects 0.93 million (0.78-1.16 million) people worldwide each year [1], leaving irretrievable debilitating sequelae. Social and economic costs resulting from sequelae further justify the development of treatments for SCI. The central nervous system (CNS), i.e., the brain and spinal cord, is considered resistant to regeneration, and treatments to restore lost tissues and functions have not yet been established, with the exception of rehabilitation that can alleviate the condition of patients to a limited extent. Recent rehabilitation has been recommended to adapt to the pathophysiological heterogeneity of SCI, which depends on the time after injury, the degree of injury, and the spinal level of injury [2].

In recent years, stem cells, which have pluripotency and renewal ability and are rich in trophic factors, have been attracting attention as a source of effective treatment for various diseases, and clinical trials with many different types of stem cells have already been conducted for SCI [3-6]. In the present review, we categorize stem cell therapies that have been proposed for SCI and carefully refer to the pathophysiology of various spinal cord injuries. Next, we discuss the mechanism of action expected for each stem cell therapy, focusing on the following pathological conditions.

The first is complete chronic injury. Although this condition is considered the most difficult to treat, some recent studies have suggested that non-functional neural tissue remaining even in such so-called complete injury can provide some functional recovery once reactivated with appropriate treatment. Harkema and colleagues have reported that 
electrical stimulation could improve a completely injured state without replenishing the nerve tissue defect [7]. In addition, there have been several reports of spinal cord injuries in which no abnormalities were observed on MRI, although the injuries were entirely symptomatic [8-10]. One of the objectives of this review is to discuss the possibility of stem cell therapy in this specific subtype of complete chronic injury, which has not been discussed so far and remains unexplored.

Next, this review focuses on cervical spinal cord injuries. Cervical spinal cord injuries account for approximately $60 \%$ of spinal cord injuries, and since symptoms extend to the upper and lower limbs, the degree of sequelae is extremely severe. However, among the countless spinal cord therapeutic studies conducted in basic research, most of them target thoracic spinal cord injuries. Only a few studies have explicitly focused on cervical SCI, and even more surprisingly, very few studies have used the contusional injury model that is the most relevant for the clinical situation [11,12]. On the other hand, unlike thoracic and lumbar spinal cord injuries, the Activity of Daily Living (ADL) in cervical spinal cord injuries depends on the spinal level of injury: the more caudal the injury, the higher the ADL. Importantly, while the non-neural component of the lesion is crucial for the response to treatment, it is possible to obtain effective functional regeneration by regenerating the non-functional neural area in cervical SCI [5], even after so-called complete injury. Thus, we will discuss what can be expected from stem cell therapy for cervical spinal cord injuries.

\section{Stem Cell Therapies for Spinal Cord Injury}

The pathophysiology of SCI is complex, involving complex dynamic interactions between multiple cell types, and cannot be treated with unidimensional approaches, i.e., those that rely on a single mechanism of action. Due to their ability to duplicate, differentiate into multiple cell types, and secrete numerous trophic factors, stem cells are ideally suited to treat the multifaceted pathophysiology of SCI.

Stem cell therapies for SCI can be broadly categorized into two categories. The first category, which involves non-neural stem cells, includes bone marrow mesenchymal stem cells (BM-MSCs), umbilical cord MSCs (UC-MSCs), and adipose tissue-derived MSCs (ADMSCs) [13-22]. Intravenous/intrathecal administration is often used, whereby engraftment to the injured area depends on a homing mechanism, and differentiation into neural cells is limited, and therefore the nervous replenishment of the lesion is also limited. However, neurotrophic factors secreted by MSCs have been shown to exert a therapeutic effect on the lesion $[23,24]$. This category of stem cell therapy with various types of MSCs, which we will refer to as supportive stem cell therapy in this review, constitutes the vast majority of clinical trials or studies in the field of SCI [18-20,25-33]. The fact that MSCs are usually easy to isolate for preparation compared with neural stem cells is a massive advantage in regulatory procedures.

The second category of stem cell therapies is based on stem cells that can generate neural cells. Olfactory ensheathing cells (OECs) [34-44], neural stem progenitor cells (NSPCs) [13,45-57], and neural progenitor cells (NPCs) derived from embryonic stem cells [58-61] or induced-pluripotent stem cells [62-65] are usually transplanted directly into the injured spinal cord. In that strategy, the transplantation procedure is invasive with special surgeries, and the preparation of the cells often requires a complex procedure. On the other hand, engraftment is the desired fate of the transplanted cells, replacing the lost neural cells and ultimately functionally substituting for them. This strategy will be referred to as loading therapy in this review. 


\section{Time-Dependent Pathological Changes after Spinal Cord Injury}

The spinal cord is located in the spinal canal, which is surrounded by the spine. When the spine is deformed due to trauma, the spinal cord undergoes mechanical damage, which is called primary injury [66,67]. Both gray and white matter, with axonal rupture for the latter, are affected at the level of the lesioned spinal cord. Numerous white matterdescending tracts that control motor function can be impaired: the corticospinal tract, the rubrospinal tract, the reticulospinal tract, the tectospinal tract, the vestibulospinal tract, and monoaminergic spinal pathways. At the same time, the mechanical shock induces edema, bleeding and ischemia, the generation of hypoxia, the disruption of intracellular ion balance with abnormal sodium influx, and the disruption of the blood-spinal cord barrier due to blood vessel disruption [66,68-70]. This primary injury is an unavoidable consequence of the injury and cannot be targeted by treatment due to its suddenness.

Immediately afterward, a condition called secondary injury begins, resulting in further cell damage, nerve fiber rupture, and demyelination [71-76]. Secondary injury involves multiple cross-related events, such as the production of inflammatory cytokines, e.g., IL-1 and $\mathrm{TNF} \alpha$, by inflammatory cells, such as leukocytes and neutrophils, which infiltrate the lesioned area, the exacerbation of edema, and the development of neuronal glutamate excitotoxicity due to the disruption of ionic balance and membrane permeability [77]. Lipid peroxidation [78], the production of free radicals and nitrogen monoxide, the dysfunction of mitochondria and the electron transfer system due to oxidative stress, and excessive proteolytic activity of various proteases due to the increased concentration of intracellular calcium [79] also contribute to this secondary injury cascade. Furthermore, edema-induced swelling of the spinal cord within the spinal canal causes increased pressure and results in further ischemia and cell damage.

Previous rodent studies have indicated that oligodendrocytes (OLs) are damaged after SCI and are lost due to cell death, resulting in the demyelination of areas of white matter [80,81]. Experiments in rats have shown that OL death begins as soon as $15 \mathrm{~min}$ after spinal cord contusion and lasts for at least three weeks. Although the kinetics may differ, SCI experiments in mice have confirmed this phenomenon with a reduction in the number of OLs within the first $24 \mathrm{~h}$ and OL death that persists from three to seven days after injury. It is also reported that the apoptosis of OLs might occur as a consequence of long-term demyelination of spared axons in the late phase after SCI, because the loss of OLs was observed in regions far distant from the lesion [80]. OL death has also been observed in tissues of human patients $[72,82,83]$, indicating that it is common to multiple types of SCI, in various species, including humans [80,84].

The secondary injury persists for several weeks after the injury. While the suggestion of steroid treatment was once of interest, no effective treatment could be confirmed in phase III of clinical trials. However, reducing secondary injury and consequently limiting inflammation-associated cell death remains an important therapeutic objective because the mitigating effect of both supportive and loading stem cell therapies is promising. During the subacute phase, i.e., the transition from the acute phase to the chronic phase, caspasemediated apoptosis, further axonal demyelination, the containment of the lesion by the fibrotic and glial scars, and extracellular matrix remodeling are progressively achieved. It is also during this phase that a partial Wallerian degeneration takes place, which is retrograde cell death due to the so-called axon rupture. The pathophysiology of the chronic phase is also associated with limited natural regeneration and will be explained in the next section.

\section{Factors Inhibiting Neuronal Regeneration}

Axons do not regenerate spontaneously after SCI even after inflammation has subsided because the injured area is not filled naturally by tissues endowed with regenerative capacity. Astrocytes proliferate but are mainly recruited to the lesion site to make a glial border. Endogenous oligodendrocyte progenitor cells (OPCs) are reported to proliferate and mostly differentiate into oligodendrocytes $[85,86]$, myelinating axons for several months. However, neurons have a small number of intrinsic precursors and do not compensate 
sufficiently for the injured part. The Wallerian degeneration of nerves whose axons are torn at the injured part is limited, and a considerable number of those cell bodies remain. Nevertheless, in addition to internal factors such as decreased axon outgrowth due to decreased intracellular cAMP concentration [87], external factors, including a lack of supportive neurotrophic factors, a cystic cavity in the center of injury that deprives axons of a physical substrate for their elongation, astrocytes, and inflammatory cells hinder axon regeneration [88-91]. In wounded tissues, scars are made up of various cells and extracellular matrix (ECM). In many organs, scar formation is directly associated with the recovery of tissue function. In contrast, the process of tissue scarring in the CNS is more ambivalent than in other tissues and does not unequivocally induce regeneration.

Specifically, scar formation in the injured CNS jointly involves fibroblast-like cell fibrosis, local inflammation by foamy macrophages that cannot process debris optimally, and corralling of the center of the lesion by reactive astrocytes [92,93]. The structure of the scar is then stabilized by various secreted ECM molecules, such as chondroitin sulfate proteoglycan (CSPG). In addition, the fragmentation of damaged axons caused by Wallerian degeneration generates debris, resulting in the extracellular deposition of myelin-related molecules (MAG, Nogo, OMgp). Together with CSPG, these molecules inhibit neuronal regeneration and neuroplasticity in the long term.

If functional tissue remains at the level of injury, the injury is classified as incomplete (Figure 1A). In natural recovery, the host axons sprout in the remaining tissue and create a detour through the surrounding healthy tissue [94-101]. After incomplete SCI in nonhuman primates, neurons of the corticospinal tract descending to the contralateral white matter have been shown to extend axons across the midline of the spinal cord and reshape the circuit. Similar phenomena have been reported for other descending tracts, such as the rubrospinal tract and the reticulospinal tract [102-104]. In those animal models, the number of axons in the descending tracts with residual axons is thought to recover partially due to lateral elongation after SCI. On the other hand, the total length of dendrites tends to increase after SCI, and this effect has been reported to be enhanced by glial cell-derived growth factor (GDNF) administration [105]. This change in the length of dendrites may be due to the elongation of individual dendrites, an increase in the number of dendrites, or a combination of both. Consistently, an increase in the size of the dendritic spines is observed concomitantly. Collectively, these changes suggest a highly plastic adaptation of the tissue around the injured area. In a hemisection model of SCI, spontaneous lateral axonal sprouting has been reported to occur around the injured site, and a new spinal cord circuit bypasses the site of the injury to generate a relay. In other words, in the case of incomplete injury, regeneration would certainly benefit from an environment that is more permissive to fiber extension in the residual tissue or reactive tissue. It seems reasonable to consider that both supportive and loading stem cell therapies can contribute to this objective.

When functional tissue does not remain in the injured area, the lesion is classified as a complete injury. Clinically, complete $\mathrm{SCI}$ is defined as the complete loss of motor and sensory function below the level of injury, with $40 \%$ of cases being A in the ASIA classification at the time of onset, but recovery is extremely limited even with conventional treatment and rehabilitation [106]. Hence, the proportion of patients with ASIA A is even higher in the chronic phase. However, recently, there have been reports of encouraging results following spinal cord epidural electrical stimulation or supportive stem cell therapy in complete SCI patients ASIA A [7]. How is function restored by a treatment method that does not supplement missing tissue in an injury where there is no residual functional tissue? Conversely, there are patients with severe symptoms whose spinal cord MRI reveals only a few abnormalities (SCIWORA) [8-10]. SCIWORA was originally a term used to describe spinal cord injury without bone abnormalities, but with the recent development of MRI, spinal cord injuries without abnormalities inside the spinal cord as well have also been reported as SCIWORA in a broader sense. Considering these observations, it is conceivable that there are two types of complete injuries: pseudo-complete SCI, in which a 
non-functional reactivable tissue remains, and true complete SCI, in which no reactivable tissue remains (Figure 1B,C) [107,108]. In pseudo-complete injury, functional recovery is expected by modifying the reactivable tissue with new therapies. Pseudo-complete injury is a promising target not only for loading stem cell therapy but also for supportive stem cell therapy.

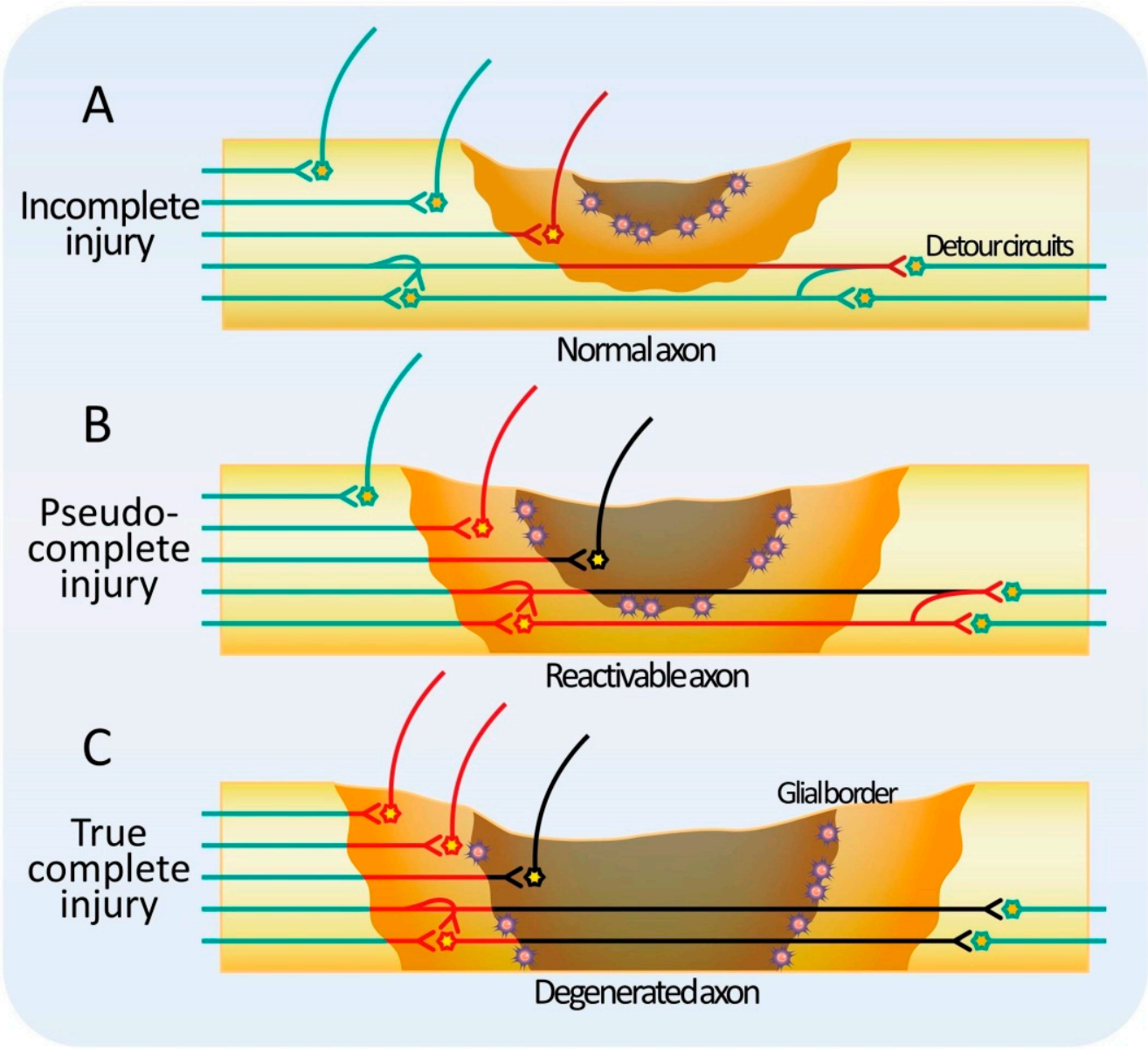

Figure 1. Classification of Spinal Cord Injuries. (A) Incomplete injury with residual functional tissue. Recovery is expected with conventional treatment. (B) Pseudo-complete injury. Non-functional but reactivable tissue (light brown) extends through the spinal cord, breaking the craniocaudal functional continuity. Recovery is difficult with conventional treatment. Functional recovery is expected by promoting axonal elongation and promoting neural activity in reactivable tissue. (C) True complete injury. Aneural tissue (gray) spans the entire spinal cord, and treatment of surrounding reactivable tissue at the rostral or caudal location does not provide a functional cranial connection.

\section{Mitigating Neurotrophic Factors}

Neurotrophic factors secreted from stem cells exert neuroprotective and anti-inflammatory effects $[13,14,53,59,109]$. In this regard, the optimal transplantation window is in the acute and subacute phases, when cell death and inflammation are maximal. Since the neuroprotective and anti-inflammatory effects start soon after transplantation, the improvement observed in motor function in experimental animals is usually observed rapidly after stem cell transplantation in the subacute phase.

Accordingly, immunostaining analyses have shown that transplanted neural stem cells reduce the accumulation of neutrophils and iNOS $+/ \mathrm{MAC}-2+$ activated macrophages in lesion areas [110]. RT-PCR analysis has also confirmed the downregulation of inflammatory cytokines such as TNF- $\alpha$, IL-1 $\beta$, IL-6, and IL-12 in this context. It is suggested that 
transplanted cells promote functional recovery after SCI by suppressing inflammationinduced secondary damage around the injured site.

Bone marrow mesenchymal stem cells have also been shown to improve function after SCI through mechanisms of neuroprotection via the secretion of neurotrophic factors, and the stabilization of the blood-spinal cord barrier $[15,111]$. RNA profiling was analyzed in the motor area of rats injected with BM-MSCs after SCI. The modification of the expression levels of potassium voltage-gated channel interacting protein 2, sodium voltage-gated channel beta subunit 3 , and phosphodiesterase $10 \mathrm{~A}$ indicates behavior-related changes that may be involved in the recovery of motor function after the systemic administration of BM-MSCs [112]. Therefore, the mitigating effect of the secretion of neurotrophic factors in supportive stem cell therapy and loading stem cell therapy appears to be a powerful mechanism of action, especially during the acute and subacute phases after SCI.

\section{Modulating Neurotrophic Factors}

In addition to suppressing inflammation and neuroprotection in the acute and subacute phases, neural stem cell-secreted neurotrophic factors have a continuous positive effect on neurons and astrocytes and result, for example, in the activation of the residual reactivable tissue remaining around the injury, which will function stably due to long-term potentiation. This is an effect that can be expected immediately after transplantation in both the subacute and chronic phases. Several trophic factors, such as brain-derived growth factor (BDNF), neurotrophin-3 (NT-3), nerve growth factor (NGF), fibroblast growth factor (FGF), and GDNF seem to exert a beneficial action on this mechanism $[14,16,59,109]$. NT-3 induces the outgrowth of axons in the corticospinal tract, while both NT-3 and NGF promote the outgrowth from the reticulum and red nucleus, respectively. BDNF induces lateral axon elongation in the rubrospinal tract, the reticular spinal tract, the vestibular spinal tract, and the anterior raphespinal tract. Using an experimental design that is not compatible with the clinical situation of SCI, a recent study in mice has identified three essential factors necessary for axon growth beyond the injured site. Osteopontin, insulinlike growth factor 1, and ciliary-derived neurotrophic factor (CNTF) were expressed in spinal neurons using a viral vector prior to injury. In addition, fibroblast growth factor-2 (FGF2) and epidermal growth factor were used to increase supportive substrates of axon growth such as laminin, and GDNF was released from synthetic hydrogel biomaterial depots placed caudally to chemoattract spinal neurons [113]. The results show that in such artificial conditions, a significant number of spinal axons could stretch across the center of injury.

In addition to anatomical regeneration, neurotrophic factors are also expected to promote the regeneration of functional circuits $[114,115]$. Synaptic activity is known to be modulated by neurotrophic factors [116-118], and the same action is anticipated for stem cell-secreted trophic factors. This action of neurotrophic factors on circuit activity is not limited to the residual circuits of the host. It will also likely increase the neural activity of new circuits formed between the host and transplanted cells.

An important question is related to the secondary effect of functional recovery of the spinal cord. After SCI, sprouting and rewiring induce the rewriting of the brain map, and functional substitutions between territories occur in the cerebral cortex $[96,97,100,102]$. Functional MRI studies have shown that changes over time are drastic [119]. In addition to the cerebral cortex, the circuits that descend from the cerebrum and brain stem to the spinal cord also change significantly after injury [120-122]. Therefore, if transplantation treatment is effective, these circuits are expected to change upon regeneration. For example, the motor-sensory area of the lower limb region, which is considered to disappear after a thoracic SCI, may reappear in other areas. In the case of dorsal injuries, the ventral reticular spinal tract tends to remain, so the cortico-reticular tract may become thicker in the hypothesis of an adaptative regeneration. Similarly, mild damage would also improve the cortico-red nucleus tract. The circuits that can cause such compensatory changes include the corticospinal tract, the rubrospinal tract, the reticulospinal tract, the 
vestibulospinal tract, the tectospinal tract, and the monoaminergic spinal tract $[95,97,122]$, as well as those superior circuits such as the cortico-red nucleus tract, the cortico-reticular formation tract, and the cortico-raphe nucleus tract [123,124]. On the caudal side of the injury, it is expected that the sensory circuits that connect with the motor neurons will also be modified $[96,98,122]$.

The long-term action of neurotrophic factors should not be underestimated. For example, sustained overexpression of NGF in the posterior horn results in the formation of inappropriate neural connections and leads to a severe nociceptive state in rats [125]. Therefore, in future preclinical studies, it is very important to define the appropriate combinations of proper growth factors and implement precise temporal administration methods to induce controlled axonal regeneration with minimal side effects.

\section{Remyelination}

Remyelination-promoting therapies are based on the premise that the function of residual demyelinated and dysfunctional nerve fibers can be restored by remyelination [126-129]. In the context of supportive stem cell therapy, this remyelination strategy requires that functional oligodendrocytes are still present. As a mechanism of action, remyelination is relatively slow because the formation of mature myelin sheath-wrapped axons is considered to take at least three weeks [130]. In the case of loading stem cell therapy, the necessary oligodendrocytes originate from the transplanted stem cells, which means that an additional period is necessary for the differentiation of the transplanted cells into mature oligodendrocytes.

A vast amount of data indicate that demyelination is the direct cause of functional symptomatic deterioration in patients with multiple sclerosis [131-135]. Experimentally, L- $\alpha$-lysophosphatidylcholine (LPC)-induced demyelinating lesions in the thoracic spinal cord caused decreased myelin binding protein (MBP) staining, resulting in deteriorated motor function assessed by two types of behavioral tests, the Beam walking test and the Ladder walking test [136]. It has also been reported that the therapeutic effect for thoracic $\mathrm{SCI}$ in mice is reduced when the transplanted neural stem cells have been prepared from MBP-free Shiverer mice, demonstrating that remyelination is a key mechanism of the motor recovery in this model [130].

In other stem cell therapies, electron microscopy analyses indicate that more myelin is derived from direct transplantation of OPCs than from NSPCs $[49,50,57,58,137]$. Strategies to transplant modified OPCs have been reported. For example, Cao et al. infected OPCs with a vector expressing CNTF and transplanted the resulting cells nine days after injury to the thoracic spinal cord [50]. The survival rate of transplanted CNTF-OPCs increased four times compared to control OPCs. As expected, the transplanted OPCs reportedly formed a central myelin sheath around the axons of the injured spinal cord. Furthermore, in rats that received CNTF-OPCs, the response to transcranial magnetic stimulation and the recovery of motor function of the hindlimbs were significantly promoted.

However, in a recent review, the overall degree of functional deterioration caused by demyelination after SCI and to which extent this demyelination contributes to recovery were called the "remyelination enigma" [4]. For example, it has been reported that genetically modified mice incapable of remyelinating recovered normally after contusive SCI [138]. It has been argued that the roles of demyelination and remyelination should be supported by further studies.

\section{Relay Mechanism}

Regarding loading stem cell therapy, the so-called relay mechanism is the most promising mechanism but also the most difficult to implement $[47,65,139,140]$. For example, in the case of motor function, the axons of the upper neurons that survive and the neurons derived from transplanted cells must first form synapses. Then, these connected graft-neurons must extend the axons caudally and form synapses with anterior horn neurons and/or 
motor-related interneurons. Considering the complexity of such a regeneration scheme, it is not surprising that the complete proof of concept remains to be established.

As mentioned above, the brain map is significantly remodeled after $\mathrm{SCI}$, as are the circuits from the brain to the brainstem $[96,97,100,102,120-122]$. In other words, there is a possibility that the original anatomical and functional circuits located rostrally to the injury disappear or change location. In addition, since the transplanted area is rich in trophic factors secreted by transplanted cells, axon invasion and synaptogenesis from the cranial host can be expected naturally, but the extension of the axon from the injured part to the caudal side requires a chemoattractant on the caudal side. It is reported that stem cells transplanted into the brain cannot extend their axons outward without an extrinsic chemoattractant [141], and the same is expected in the spinal cord. On the other hand, if enough fibers can extend caudally, a functional circuit would be formed with caudal host tissue [120]. During CNS development, a phenomenon known as pruning, i.e., the elimination of supernumerary nonactive connections, allows the selection of only the functional circuits [142]. This mechanism is expected to be involved in the regeneration processes that follow stem cell therapy.

To date, there are many examples of circuits formed between the host and transplanted cells $[47,62,65]$. The first line of evidence comes from the juxtaposition of neurites derived from transplanted cells labeled by $\beta$-III tubulin and $\mathrm{hNu}$ antibodies, and the presynaptic region of Bassoon-stained host neurons in the mouse spinal cord. Immunoelectron microscopy confirmed this interaction by visualizing transplanted cells through GFP expression and host mouse synapses. Furthermore, reports using the rabies virus as a transsynaptic tracer have shown that transplanted cells can form synapses in the brain stem and the caudal side. However, there are still no reports that directly show that upper neurons are bridged to lower neurons via transplanted cells.

The relay mechanism requires sufficient time for the axon to gradually elongate before any effect can be expected after the transplantation. The axon elongation rate of transplanted cells has been evaluated to $\sim 1-2 \mathrm{~mm} /$ day, representing approximately 10 days to travel a distance of $20 \mathrm{~mm}$ from a thoracic injury to the lumbar spinal cord of a rat, not including the prior period for the differentiation of neural stem cells into neurons. How much time would be necessary for a human patient? The relay mechanism is the only mechanism that bridges the upper and lower circuits through true complete injury, but its practical realization is still a long way ahead and requires further research.

\section{Specificity of Cervical Spinal Cord Injury}

There are many reasons to explain the scarcity of clinically relevant reports on the treatment of cervical spinal cord injuries: the difficulty of assessing upper limb function, respiratory impairment, the spinal shock, and the complexity of managing quadriplegia, associated with ethical and care issues $[3,143,144]$. However, cervical spinal cord injuries account for $60 \%$ of spinal cord injuries [145] and represent a more severe clinical condition because they affect both upper and lower limbs. Among spinal cord injuries, the social need for treatment is the highest for cervical spinal cord injuries. Meanwhile, in the cervical cord, the innervated muscles of the upper limbs are relatively clearly separated for each medullary segment. Furthermore, since the upper limbs have more functions than the lower limbs, the ADL is completely different depending on the level of disability (Figure 2A) [146]. For example, if the functional range extends to C6, it will be possible to drive a car. Segmented functionalization of the cervical spinal cord is the most promising target because a significant therapeutic outcome, such as ADL in clinical trials, can be achieved by slight shifts in the medullary segments involved. 
A

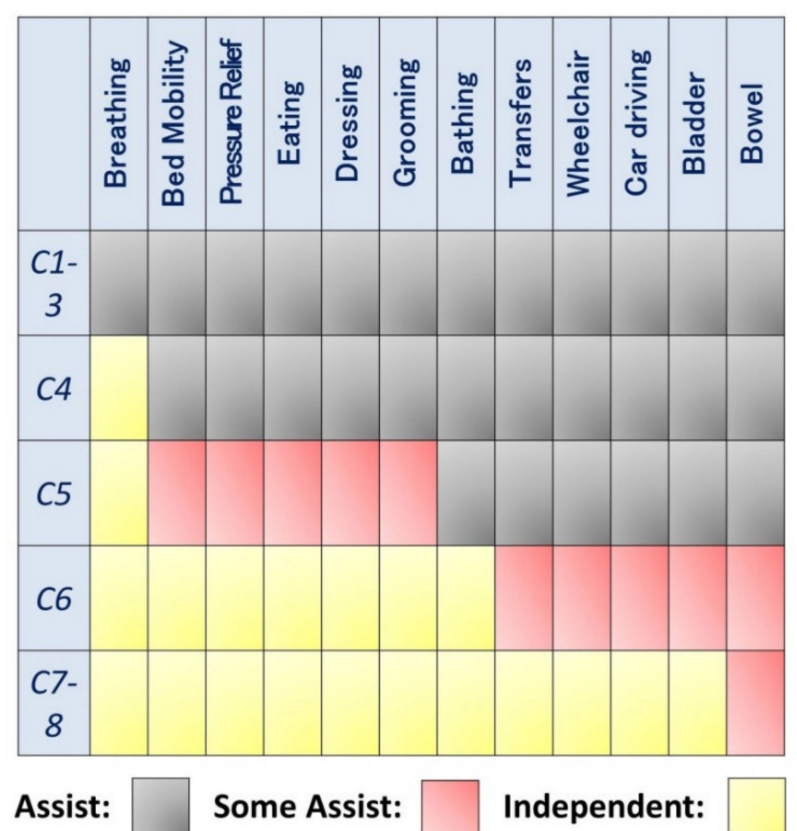

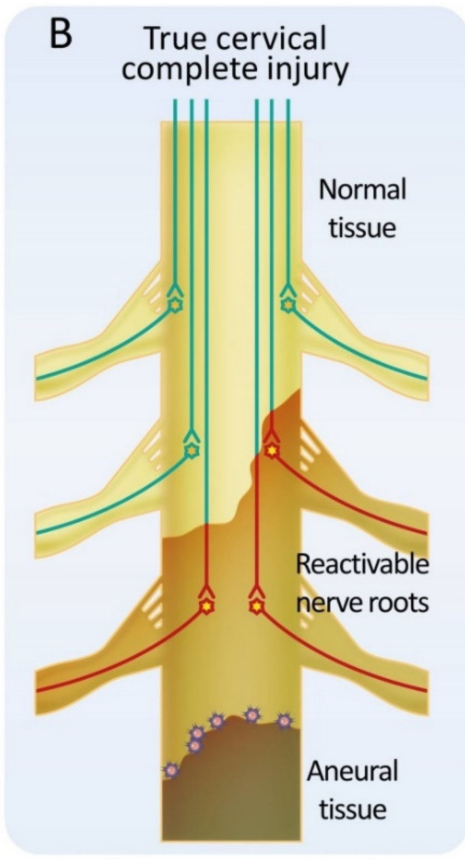

Figure 2. Specificity of Cervical Spinal Cord Injury. (A) Expected Activity of Daily Living (ADL) subcategories in various levels of cervical spinal cord injury. Unlike thoracic and lumbar injuries, slight differences in the spinal level of injury increase the independent ADL. Modified from reference [146]. (B) True complete cervical cord injury. The aneural area crosses the spinal cord (gray), but the reactivable tissue (light brown) around it remains. The ADL of patients is expected to increase as the reactivable tissue becomes functional from stem cell therapy.

We have mentioned the existence of pseudo-complete injury in which some nonfunctional but reactivable tissue remains, even in functionally complete injury. Cervical spinal cord injuries include incomplete injuries, pseudo-complete injuries, and true complete injuries. In incomplete and pseudo-complete injuries, the mechanism of stem cell therapy is expected to involve mostly tissue-reactivating neurotrophic factors, as mentioned previously. For example, ASIA grade A patients in whom residual tissue was observed on MRI, i.e., corresponding to pseudo-complete injury, had a functional improvement of the injured caudal side by the administration of BM-MSCs [147]. When considering true complete injury of thoracic and lumbar spinal cord, the lesion is devoid of nerve tissue, and functional recovery with stem cell therapy would exclusively depend on the relay mechanism. In contrast, in a true complete injury of the cervical cord, the functional medullary level is expected to be widened by functionalizing reactivable tissue on the cranial side of the injury, which will directly lead to improved ADL (Figure 2B).

For the regenerative treatment of true complete injury, the usual objective is to restore the function of the caudal side of the injury. However, in the case of true complete injury of the cervical cord, the success of clinical trials should be evaluated with appropriate primary objectives, such as an expansion of the functional level on the cranial side of the injury and an accompanying increase in ADL.

\section{Combination with Modified Rehabilitation}

Multiple clinical trials have been conducted for SCI, but to date, only those related to rehabilitation had beneficial outcomes. There are few comparative clinical reports on combinational treatment with stem cell therapy because it is ethically difficult to treat SCI patients without rehabilitation. As an experimental study, it is reported that the transplantation of NSPCs and conventional treadmill rehabilitation with thoracic SCI mice in the chronic phase demonstrated the functional recovery of hindlimbs, suggesting the synergic effect at the lumbar enlargement [148]. 
Modified rehabilitations, which intend to modulate neural circuits, have been reported [149]. It is relatively easy to make an intervention on peripheral nerves, and wearable devices have been developed for functional electrical stimulation (FES) [150]. FES detects slight contractions of muscles and turns them into large stimuli, and repetitive cycles of inputs and outputs enhance the neural circuits. The Robot Suit HAL (hybrid assistive limb) expands this feedback using exoskeletons, and converts the electromyogram into a mechanical output to support joint movement and augment the neural circuit through feedback from sensory inputs [151]. Furthermore, as described above, neural plasticity exists not only around the lesion area, but also around the superior neural circuits, and there are studies describing the effectiveness of neurofeedback using electroencephalogram $[149,152]$. As the synergic effect was achieved with conventional rehabilitation, a combinational protocol of stem cell therapies with neurofeedback rehabilitation will be described in a future study.

\section{Combination with Electrical/Magnetic Stimulation}

Electrical/magnetic stimulation therapy as well as stem cell therapy has recently gained much attention [12,122,153-168]. Different types of stimulation have been applied to treat SCI: transcranial magnetic stimulation, therapeutic electrostimulation, peripheral nerve electrostimulation, transcutaneous nervous electrostimulation, subdural electrostimulation, epidural electrostimulation, subdural electrostimulation, deep-brain stimulation, and brain surface epidural electrostimulation that mimics transcranial magnetic stimulation.

In the case of methods that directly stimulate the spinal cord, such as epidural electrostimulation, subdural electrostimulation, and intraspinal electrostimulation, the stimulation of the input and output circuits of the spinal cord promotes the adjustment of posture and intensity of effort, and restores spontaneous motor control [169,170]. Complications of SCI such as flexor spasms, hyperreflexia, and spasticity may also result from inappropriate lateral sprouting and synaptic hyperplasia of motor neurons that have lost cortical input after injury. It is possible that electrostimulation sufficiently activates motor neurons and suppresses this excessive afferent synaptogenesis. Initially, these electrostimulation treatments were thought to modify and improve the remaining neural circuits. However, there are reports of effective electrostimulation in patients with ASIA A (complete injury) [7], suggesting that non-functional but reactivable tissue is also activated. There are reports describing the combinational effect of magnetic stimulation and stem cell therapy, and synergistic effects of those stimulations with stem cell therapy would be expected.

\section{Conclusions}

By targeting the non-functional reactivable tissue around the injured area, different regeneration mechanisms of stem cell therapy can be expected, even without direct transplantation into the injured area. In addition, since treatment for cervical SCI has high social needs and is likely to be effective according to its pathology, it is necessary to conduct research with appropriate objectives.

Author Contributions: Writing (original draft preparation), M.S.; writing (review and editing), M.S. and H.O.; supervision, H.O., N.N. and M.N. All authors have read and agreed to the published version of the manuscript.

Funding: The APC was funded by the Japan Agency for Medical Research and Development (AMED; grant nos. 19bm0204001h007 and 19bk0104017h002 to H.O. and M.N.).

Acknowledgments: We appreciate the assistance provided by S. Shibata, J. Koyama, S. Nori, O. Tsuji, K. Sugai, and S. Kawashima, all of whom are members of the spinal cord research team in the Department of Orthopedic Surgery and Physiology, Keio University School of Medicine, Tokyo, Japan. This work was supported by the Japan Agency for Medical Research and Development (AMED; grant nos. 19bm0204001h007 and 19bk0104017h002 to H.O. and M.N.).

Conflicts of Interest: H.O. declared a leadership position at Keio University School of Medicine and is a compensated scientific consultant for San BioCo. Ltd., Tokyo, Japan and K Pharma Inc. M.N., 
Tokyo, Japan declared a consultancy role with K-Pharma Inc. and research funding from RMic and Hisamitsu. The other authors declared no potential conflicts of interest.

\section{References}

1. Injury, G.B.D.T.B.; Spinal Cord Injury, C. Global, regional, and national burden of traumatic brain injury and spinal cord injury, 1990-2016: A systematic analysis for the Global Burden of Disease Study 2016. Lancet Neurol. 2019, 18, 56-87. [CrossRef]

2. Rapidi, C.A.; Tederko, P.; Moslavac, S.; Popa, D.; Branco, C.A.; Kiekens, C.; Varela Donoso, E.; Christodoulou, N.; Professional Practice Committee of the UEMS-PRM Section. Evidence-based position paper on Physical and Rehabilitation Medicine (PRM) professional practice for persons with spinal cord injury. The European PRM position (UEMS PRM Section). Eur. J. Phys. Rehabil. Med. 2018, 54, 797-807. [CrossRef]

3. Tetzlaff, W.; Okon, E.B.; Karimi-Abdolrezaee, S.; Hill, C.E.; Sparling, J.S.; Plemel, J.R.; Plunet, W.T.; Tsai, E.C.; Baptiste, D.; Smithson, L.J.; et al. A systematic review of cellular transplantation therapies for spinal cord injury. J. Neurotrauma 2011, 28, 1611-1682. [CrossRef] [PubMed]

4. Fischer, I.; Dulin, J.N.; Lane, M.A. Transplanting neural progenitor cells to restore connectivity after spinal cord injury. Nat. Rev. Neurosci. 2020, 21, 366-383. [CrossRef] [PubMed]

5. Courtine, G.; Sofroniew, M.V. Spinal cord repair: Advances in biology and technology. Nat. Med. 2019, 25, 898-908. [CrossRef] [PubMed]

6. Assinck, P.; Duncan, G.J.; Hilton, B.J.; Plemel, J.R.; Tetzlaff, W. Cell transplantation therapy for spinal cord injury. Nat. Neurosci. 2017, 20, 637-647. [CrossRef]

7. Angeli, C.A.; Boakye, M.; Morton, R.A.; Vogt, J.; Benton, K.; Chen, Y.; Ferreira, C.K.; Harkema, S.J. Recovery of Over-Ground Walking after Chronic Motor Complete Spinal Cord Injury. N. Engl. J. Med. 2018, 379, 1244-1250. [CrossRef] [PubMed]

8. Boese, C.K.; Muller, D.; Broer, R.; Eysel, P.; Krischek, B.; Lehmann, H.C.; Lechler, P. Spinal cord injury without radiographic abnormality (SCIWORA) in adults: MRI type predicts early neurologic outcome. Spinal Cord 2016, 54, 878-883. [CrossRef]

9. Brauge, D.; Plas, B.; Vinchon, M.; Charni, S.; Di Rocco, F.; Sacko, O.; Mrozek, S.; Sales de Gauzy, J. Multicenter study of 37 pediatric patients with SCIWORA or other spinal cord injury without associated bone lesion. Orthop. Traumatol. Surg. Res. 2020, 106, 167-171. [CrossRef] [PubMed]

10. Kasimatis, G.B.; Panagiotopoulos, E.; Megas, P.; Matzaroglou, C.; Gliatis, J.; Tyllianakis, M.; Lambiris, E. The adult spinal cord injury without radiographic abnormalities syndrome: Magnetic resonance imaging and clinical findings in adults with spinal cord injuries having normal radiographs and computed tomography studies. J. Trauma 2008, 65, 86-93. [CrossRef]

11. Anderson, K.D.; Sharp, K.G.; Steward, O. Bilateral cervical contusion spinal cord injury in rats. Exp. Neurol. 2009, $220,9-22$. [CrossRef] [PubMed]

12. Zareen, N.; Shinozaki, M.; Ryan, D.; Alexander, H.; Amer, A.; Truong, D.Q.; Khadka, N.; Sarkar, A.; Naeem, S.; Bikson, M.; et al. Motor cortex and spinal cord neuromodulation promote corticospinal tract axonal outgrowth and motor recovery after cervical contusion spinal cord injury. Exp. Neurol. 2017, 297, 179-189. [CrossRef] [PubMed]

13. Hawryluk, G.W.; Mothe, A.; Wang, J.; Wang, S.; Tator, C.; Fehlings, M.G. An in vivo characterization of trophic factor production following neural precursor cell or bone marrow stromal cell transplantation for spinal cord injury. Stem Cells Dev. 2012, 21, 2222-2238. [CrossRef] [PubMed]

14. Gu, W.; Zhang, F.; Xue, Q.; Ma, Z.; Lu, P.; Yu, B. Transplantation of bone marrow mesenchymal stem cells reduces lesion volume and induces axonal regrowth of injured spinal cord. Neuropathology 2010, 30, 205-217. [CrossRef]

15. Abrams, M.B.; Dominguez, C.; Pernold, K.; Reger, R.; Wiesenfeld-Hallin, Z.; Olson, L.; Prockop, D. Multipotent mesenchymal stromal cells attenuate chronic inflammation and injury-induced sensitivity to mechanical stimuli in experimental spinal cord injury. Restor. Neurol. Neurosci. 2009, 27, 307-321. [CrossRef] [PubMed]

16. Ritfeld, G.J.; Patel, A.; Chou, A.; Novosat, T.L.; Castillo, D.G.; Roos, R.A.; Oudega, M. The role of brain-derived neurotrophic factor in bone marrow stromal cell-mediated spinal cord repair. Cell Transplant. 2015, 24, 2209-2220. [CrossRef] [PubMed]

17. Hur, J.W.; Cho, T.H.; Park, D.H.; Lee, J.B.; Park, J.Y.; Chung, Y.G. Intrathecal transplantation of autologous adipose-derived mesenchymal stem cells for treating spinal cord injury: A human trial. J. Spinal Cord Med. 2016, 39, 655-664. [CrossRef]

18. Cheng, H.; Liu, X.; Hua, R.; Dai, G.; Wang, X.; Gao, J.; An, Y. Clinical observation of umbilical cord mesenchymal stem cell transplantation in treatment for sequelae of thoracolumbar spinal cord injury. J. Transl. Med. 2014, 12, 253. [CrossRef]

19. Dai, G.; Liu, X.; Zhang, Z.; Yang, Z.; Dai, Y.; Xu, R. Transplantation of autologous bone marrow mesenchymal stem cells in the treatment of complete and chronic cervical spinal cord injury. Brain Res. 2013, 1533, 73-79. [CrossRef]

20. El-Kheir, W.A.; Gabr, H.; Awad, M.R.; Ghannam, O.; Barakat, Y.; Farghali, H.A.; El Maadawi, Z.M.; Ewes, I.; Sabaawy, H.E. Autologous bone marrow-derived cell therapy combined with physical therapy induces functional improvement in chronic spinal cord injury patients. Cell Transplant. 2014, 23, 729-745. [CrossRef]

21. de Almeida, F.M.; Marques, S.A.; Ramalho Bdos, S.; Massoto, T.B.; Martinez, A.M. Chronic spinal cord lesions respond positively to tranplants of mesenchymal stem cells. Restor. Neurol. Neurosci. 2015, 33, 43-55. [CrossRef] [PubMed]

22. Lee, S.H.; Kim, Y.; Rhew, D.; Kim, A.; Jo, K.R.; Yoon, Y.; Choi, K.U.; Jung, T.; Kim, W.H.; Kweon, O.K. Effect of canine mesenchymal stromal cells overexpressing heme oxygenase-1 in spinal cord injury. J. Vet. Sci. 2017, 18, 377-386. [CrossRef]

23. Pinho, A.G.; Cibrao, J.R.; Silva, N.A.; Monteiro, S.; Salgado, A.J. Cell Secretome: Basic Insights and Therapeutic Opportunities for CNS Disorders. Pharmaceuticals 2020, 13, 31. [CrossRef] [PubMed] 
24. Vawda, R.; Badner, A.; Hong, J.; Mikhail, M.; Dragas, R.; Xhima, K.; Jose, A.; Fehlings, M.G. Harnessing the Secretome of Mesenchymal Stromal Cells for Traumatic Spinal Cord Injury: Multicell Comparison and Assessment of In Vivo Efficacy. Stem Cells Dev. 2020, 29, 1429-1443. [CrossRef] [PubMed]

25. Karamouzian, S.; Nematollahi-Mahani, S.N.; Nakhaee, N.; Eskandary, H. Clinical safety and primary efficacy of bone marrow mesenchymal cell transplantation in subacute spinal cord injured patients. Clin. Neurol. Neurosurg. 2012, 114, 935-939. [CrossRef]

26. Mendonca, M.V.; Larocca, T.F.; de Freitas Souza, B.S.; Villarreal, C.F.; Silva, L.F.; Matos, A.C.; Novaes, M.A.; Bahia, C.M.; de Oliveira Melo Martinez, A.C.; Kaneto, C.M.; et al. Safety and neurological assessments after autologous transplantation of bone marrow mesenchymal stem cells in subjects with chronic spinal cord injury. Stem Cell Res. Ther. 2014, 5, 126. [CrossRef]

27. Vaquero, J.; Zurita, M.; Rico, M.A.; Aguayo, C.; Bonilla, C.; Marin, E.; Tapiador, N.; Sevilla, M.; Vazquez, D.; Carballido, J.; et al. Intrathecal administration of autologous mesenchymal stromal cells for spinal cord injury: Safety and efficacy of the $100 / 3$ guideline. Cytotherapy 2018, 20, 806-819. [CrossRef] [PubMed]

28. Oh, S.K.; Choi, K.H.; Yoo, J.Y.; Kim, D.Y.; Kim, S.J.; Jeon, S.R. A Phase III Clinical Trial Showing Limited Efficacy of Autologous Mesenchymal Stem Cell Therapy for Spinal Cord Injury. Neurosurgery 2016, 78, 436-447, discussion 447. [CrossRef]

29. Vaquero, J.; Zurita, M.; Rico, M.A.; Bonilla, C.; Aguayo, C.; Fernandez, C.; Tapiador, N.; Sevilla, M.; Morejon, C.; Montilla, J.; et al. Repeated subarachnoid administrations of autologous mesenchymal stromal cells supported in autologous plasma improve quality of life in patients suffering incomplete spinal cord injury. Cytotherapy 2017, 19, 349-359. [CrossRef]

30. Ra, J.C.; Shin, I.S.; Kim, S.H.; Kang, S.K.; Kang, B.C.; Lee, H.Y.; Kim, Y.J.; Jo, J.Y.; Yoon, E.J.; Choi, H.J.; et al. Safety of intravenous infusion of human adipose tissue-derived mesenchymal stem cells in animals and humans. Stem Cells Dev. 2011, 20, 1297-1308. [CrossRef]

31. Pal, R.; Venkataramana, N.K.; Bansal, A.; Balaraju, S.; Jan, M.; Chandra, R.; Dixit, A.; Rauthan, A.; Murgod, U.; Totey, S. Ex vivo-expanded autologous bone marrow-derived mesenchymal stromal cells in human spinal cord injury/paraplegia: A pilot clinical study. Cytotherapy 2009, 11, 897-911. [CrossRef]

32. Vaquero, J.; Zurita, M.; Rico, M.A.; Bonilla, C.; Aguayo, C.; Montilla, J.; Bustamante, S.; Carballido, J.; Marin, E.; Martinez, F.; et al. An approach to personalized cell therapy in chronic complete paraplegia: The Puerta de Hierro phase I/II clinical trial. Cytotherapy 2016, 18, 1025-1036. [CrossRef]

33. Phedy, P.; Djaja, Y.P.; Gatam, L.; Kusnadi, Y.; Wirawan, R.P.; Tobing, I.M.S.; Subakir, N.; Mappalilu, A.; Prawira, M.A.; Yauwenas, R.; et al. Motoric Recovery After Transplantation of Bone Marrow Derived Mesenchymal Stem Cells in Chronic Spinal Cord Injury: A Case Report. Am. J. Case Rep. 2019, 20, 1299-1304. [CrossRef]

34. Lopez-Vales, R.; Fores, J.; Navarro, X.; Verdu, E. Chronic transplantation of olfactory ensheathing cells promotes partial recovery after complete spinal cord transection in the rat. Glia 2007, 55, 303-311. [CrossRef]

35. Lopez-Vales, R.; Garcia-Alias, G.; Fores, J.; Navarro, X.; Verdu, E. Increased expression of cyclo-oxygenase 2 and vascular endothelial growth factor in lesioned spinal cord by transplanted olfactory ensheathing cells. J. Neurotrauma 2004, 21, 1031-1043. [CrossRef] [PubMed]

36. Verdu, E.; Garcia-Alias, G.; Fores, J.; Lopez-Vales, R.; Navarro, X. Olfactory ensheathing cells transplanted in lesioned spinal cord prevent loss of spinal cord parenchyma and promote functional recovery. Glia 2003, 42, 275-286. [CrossRef] [PubMed]

37. Ramer, L.M.; Richter, M.W.; Roskams, A.J.; Tetzlaff, W.; Ramer, M.S. Peripherally-derived olfactory ensheathing cells do not promote primary afferent regeneration following dorsal root injury. Glia 2004, 47, 189-206. [CrossRef]

38. Richter, M.W.; Fletcher, P.A.; Liu, J.; Tetzlaff, W.; Roskams, A.J. Lamina propria and olfactory bulb ensheathing cells exhibit differential integration and migration and promote differential axon sprouting in the lesioned spinal cord. J. Neurosci. 2005, 25, 10700-10711. [CrossRef]

39. Takeoka, A.; Jindrich, D.L.; Munoz-Quiles, C.; Zhong, H.; van den Brand, R.; Pham, D.L.; Ziegler, M.D.; Ramon-Cueto, A.; Roy, R.R.; Edgerton, V.R.; et al. Axon regeneration can facilitate or suppress hindlimb function after olfactory ensheathing glia transplantation. J. Neurosci. 2011, 31, 4298-4310. [CrossRef] [PubMed]

40. Fouad, K.; Schnell, L.; Bunge, M.B.; Schwab, M.E.; Liebscher, T.; Pearse, D.D. Combining Schwann cell bridges and olfactoryensheathing glia grafts with chondroitinase promotes locomotor recovery after complete transection of the spinal cord. J. Neurosci. 2005, 25, 1169-1178. [CrossRef]

41. Watzlawick, R.; Rind, J.; Sena, E.S.; Brommer, B.; Zhang, T.; Kopp, M.A.; Dirnagl, U.; Macleod, M.R.; Howells, D.W.; Schwab, J.M. Olfactory Ensheathing Cell Transplantation in Experimental Spinal Cord Injury: Effect size and Reporting Bias of 62 Experimental Treatments: A Systematic Review and Meta-Analysis. PLoS Biol. 2016, 14, e1002468. [CrossRef]

42. Zamani, H.; Soufizomorrod, M.; Oraee-Yazdani, S.; Naviafar, D.; Akhlaghpasand, M.; Seddighi, A.; Soleimani, M. Safety and feasibility of autologous olfactory ensheathing cell and bone marrow mesenchymal stem cell co-transplantation in chronic human spinal cord injury: A clinical trial. Spinal Cord 2021. [CrossRef]

43. Gilmour, A.D.; Reshamwala, R.; Wright, A.A.; Ekberg, J.A.K.; St John, J.A. Optimizing Olfactory Ensheathing Cell Transplantation for Spinal Cord Injury Repair. J. Neurotrauma 2020, 37, 817-829. [CrossRef]

44. Khankan, R.R.; Griffis, K.G.; Haggerty-Skeans, J.R.; Zhong, H.; Roy, R.R.; Edgerton, V.R.; Phelps, P.E. Olfactory Ensheathing Cell Transplantation after a Complete Spinal Cord Transection Mediates Neuroprotective and Immunomodulatory Mechanisms to Facilitate Regeneration. J. Neurosci. 2016, 36, 6269-6286. [CrossRef]

45. Stokes, B.T.; Reier, P.J. Oxygen transport in intraspinal fetal grafts: Graft-host relations. Exp. Neurol. 1991, 111, 312-323. [CrossRef] 
46. Horner, P.J.; Stokes, B.T. Fetal transplantation following spinal contusion injury results in chronic alterations in CNS glucose metabolism. Exp. Neurol. 1995, 133, 231-243. [CrossRef]

47. Lu, P.; Wang, Y.; Graham, L.; McHale, K.; Gao, M.; Wu, D.; Brock, J.; Blesch, A.; Rosenzweig, E.S.; Havton, L.A.; et al. Long-distance growth and connectivity of neural stem cells after severe spinal cord injury. Cell 2012, 150, 1264-1273. [CrossRef] [PubMed]

48. Steward, O.; Sharp, K.G.; Yee, K.M.; Hatch, M.N.; Bonner, J.F. Characterization of ectopic colonies that form in widespread areas of the nervous system with neural stem cell transplants into the site of a severe spinal cord injury. J. Neurosci. 2014, 34, 14013-14021. [CrossRef]

49. Cao, Q.; Xu, X.M.; Devries, W.H.; Enzmann, G.U.; Ping, P.; Tsoulfas, P.; Wood, P.M.; Bunge, M.B.; Whittemore, S.R. Functional recovery in traumatic spinal cord injury after transplantation of multineurotrophin-expressing glial-restricted precursor cells. $J$. Neurosci. 2005, 25, 6947-6957. [CrossRef] [PubMed]

50. Cao, Q.; He, Q.; Wang, Y.; Cheng, X.; Howard, R.M.; Zhang, Y.; DeVries, W.H.; Shields, C.B.; Magnuson, D.S.; Xu, X.M.; et al. Transplantation of ciliary neurotrophic factor-expressing adult oligodendrocyte precursor cells promotes remyelination and functional recovery after spinal cord injury. J. Neurosci. 2010, 30, 2989-3001. [CrossRef]

51. Plemel, J.R.; Chojnacki, A.; Sparling, J.S.; Liu, J.; Plunet, W.; Duncan, G.J.; Park, S.E.; Weiss, S.; Tetzlaff, W. Platelet-derived growth factor-responsive neural precursors give rise to myelinating oligodendrocytes after transplantation into the spinal cords of contused rats and dysmyelinated mice. Glia 2011, 59, 1891-1910. [CrossRef]

52. Karimi-Abdolrezaee, S.; Eftekharpour, E.; Wang, J.; Morshead, C.M.; Fehlings, M.G. Delayed transplantation of adult neural precursor cells promotes remyelination and functional neurological recovery after spinal cord injury. J. Neurosci. 2006, 26, 3377-3389. [CrossRef] [PubMed]

53. Cusimano, M.; Biziato, D.; Brambilla, E.; Donega, M.; Alfaro-Cervello, C.; Snider, S.; Salani, G.; Pucci, F.; Comi, G.; Garcia-Verdugo, J.M.; et al. Transplanted neural stem/precursor cells instruct phagocytes and reduce secondary tissue damage in the injured spinal cord. Brain 2012, 135, 447-460. [CrossRef]

54. Hawryluk, G.W.; Spano, S.; Chew, D.; Wang, S.; Erwin, M.; Chamankhah, M.; Forgione, N.; Fehlings, M.G. An examination of the mechanisms by which neural precursors augment recovery following spinal cord injury: A key role for remyelination. Cell Transplant. 2014, 23, 365-380. [CrossRef] [PubMed]

55. Piltti, K.M.; Salazar, D.L.; Uchida, N.; Cummings, B.J.; Anderson, A.J. Safety of epicenter versus intact parenchyma as a transplantation site for human neural stem cells for spinal cord injury therapy. Stem Cells Transl. Med. 2013, 2, 204-216. [CrossRef]

56. Sontag, C.J.; Uchida, N.; Cummings, B.J.; Anderson, A.J. Injury to the spinal cord niche alters the engraftment dynamics of human neural stem cells. Stem Cell Rep. 2014, 2, 620-632. [CrossRef] [PubMed]

57. Hwang, D.H.; Kim, B.G.; Kim, E.J.; Lee, S.I.; Joo, I.S.; Suh-Kim, H.; Sohn, S.; Kim, S.U. Transplantation of human neural stem cells transduced with Olig2 transcription factor improves locomotor recovery and enhances myelination in the white matter of rat spinal cord following contusive injury. BMC Neurosci. 2009, 10, 117. [CrossRef]

58. Keirstead, H.S.; Nistor, G.; Bernal, G.; Totoiu, M.; Cloutier, F.; Sharp, K.; Steward, O. Human embryonic stem cell-derived oligodendrocyte progenitor cell transplants remyelinate and restore locomotion after spinal cord injury. J. Neurosci. 2005, 25, 4694-4705. [CrossRef]

59. Sharp, J.; Frame, J.; Siegenthaler, M.; Nistor, G.; Keirstead, H.S. Human embryonic stem cell-derived oligodendrocyte progenitor cell transplants improve recovery after cervical spinal cord injury. Stem Cells 2010, 28, 152-163. [CrossRef]

60. Lien, B.V.; Tuszynski, M.H.; Lu, P. Astrocytes migrate from human neural stem cell grafts and functionally integrate into the injured rat spinal cord. Exp. Neurol. 2019, 314, 46-57. [CrossRef] [PubMed]

61. Lu, P.; Ceto, S.; Wang, Y.; Graham, L.; Wu, D.; Kumamaru, H.; Staufenberg, E.; Tuszynski, M.H. Prolonged human neural stem cell maturation supports recovery in injured rodent CNS. J. Clin. Invest. 2017, 127, 3287-3299. [CrossRef] [PubMed]

62. Nori, S.; Okada, Y.; Yasuda, A.; Tsuji, O.; Takahashi, Y.; Kobayashi, Y.; Fujiyoshi, K.; Koike, M.; Uchiyama, Y.; Ikeda, E.; et al. Grafted human-induced pluripotent stem-cell-derived neurospheres promote motor functional recovery after spinal cord injury in mice. Proc. Natl. Acad. Sci. USA 2011, 108, 16825-16830. [CrossRef]

63. Nori, S.; Okada, Y.; Nishimura, S.; Sasaki, T.; Itakura, G.; Kobayashi, Y.; Renault-Mihara, F.; Shimizu, A.; Koya, I.; Yoshida, R.; et al. Long-term safety issues of iPSC-based cell therapy in a spinal cord injury model: Oncogenic transformation with epithelial-mesenchymal transition. Stem Cell Rep. 2015, 4, 360-373. [CrossRef]

64. Kobayashi, Y.; Okada, Y.; Itakura, G.; Iwai, H.; Nishimura, S.; Yasuda, A.; Nori, S.; Hikishima, K.; Konomi, T.; Fujiyoshi, K.; et al. Pre-evaluated safe human iPSC-derived neural stem cells promote functional recovery after spinal cord injury in common marmoset without tumorigenicity. PLoS ONE 2012, 7, e52787. [CrossRef]

65. Kadoya, K.; Lu, P.; Nguyen, K.; Lee-Kubli, C.; Kumamaru, H.; Yao, L.; Knackert, J.; Poplawski, G.; Dulin, J.N.; Strobl, H.; et al. Spinal cord reconstitution with homologous neural grafts enables robust corticospinal regeneration. Nat. Med. 2016, 22, 479-487. [CrossRef]

66. Tator, C.H.; Fehlings, M.G. Review of the secondary injury theory of acute spinal cord trauma with emphasis on vascular mechanisms. J. Neurosurg. 1991, 75, 15-26. [CrossRef] [PubMed]

67. Okon, E.B.; Streijger, F.; Lee, J.H.; Anderson, L.M.; Russell, A.K.; Kwon, B.K. Intraparenchymal microdialysis after acute spinal cord injury reveals differential metabolic responses to contusive versus compressive mechanisms of injury. J. Neurotrauma 2013, 30, 1564-1576. [CrossRef] 
68. Mautes, A.E.; Weinzierl, M.R.; Donovan, F.; Noble, L.J. Vascular events after spinal cord injury: Contribution to secondary pathogenesis. Phys. Ther. 2000, 80, 673-687. [CrossRef] [PubMed]

69. Noble, L.J.; Wrathall, J.R. Distribution and time course of protein extravasation in the rat spinal cord after contusive injury. Brain Res. 1989, 482, 57-66. [CrossRef]

70. Noble, L.J.; Wrathall, J.R. Correlative analyses of lesion development and functional status after graded spinal cord contusive injuries in the rat. Exp. Neurol. 1989, 103, 34-40. [CrossRef]

71. Kwon, B.K.; Tetzlaff, W.; Grauer, J.N.; Beiner, J.; Vaccaro, A.R. Pathophysiology and pharmacologic treatment of acute spinal cord injury. Spine J. 2004, 4, 451-464. [CrossRef] [PubMed]

72. Norenberg, M.D.; Smith, J.; Marcillo, A. The pathology of human spinal cord injury: Defining the problems. J. Neurotrauma 2004, 21, 429-440. [CrossRef]

73. Oyinbo, C.A. Secondary injury mechanisms in traumatic spinal cord injury: A nugget of this multiply cascade. Acta Neurobiol. Exp. 2011, 71, 281-299.

74. Plemel, J.R.; Wee Yong, V.; Stirling, D.P. Immune modulatory therapies for spinal cord injury-past, present and future. Exp. Neurol. 2014, 258, 91-104. [CrossRef]

75. Gadani, S.P.; Walsh, J.T.; Lukens, J.R.; Kipnis, J. Dealing with Danger in the CNS: The Response of the Immune System to Injury. Neuron 2015, 87, 47-62. [CrossRef] [PubMed]

76. Jones, T.B.; McDaniel, E.E.; Popovich, P.G. Inflammatory-mediated injury and repair in the traumatically injured spinal cord. Curr. Pharm. Des. 2005, 11, 1223-1236. [CrossRef]

77. Park, E.; Velumian, A.A.; Fehlings, M.G. The role of excitotoxicity in secondary mechanisms of spinal cord injury: A review with an emphasis on the implications for white matter degeneration. J. Neurotrauma 2004, 21, 754-774. [CrossRef]

78. Bao, F.; Chen, Y.; Dekaban, G.A.; Weaver, L.C. Early anti-inflammatory treatment reduces lipid peroxidation and protein nitration after spinal cord injury in rats. J. Neurochem. 2004, 88, 1335-1344. [CrossRef]

79. Festoff, B.W.; Ameenuddin, S.; Arnold, P.M.; Wong, A.; Santacruz, K.S.; Citron, B.A. Minocycline neuroprotects, reduces microgliosis, and inhibits caspase protease expression early after spinal cord injury. J. Neurochem. 2006, 97, 1314-1326. [CrossRef]

80. Crowe, M.J.; Bresnahan, J.C.; Shuman, S.L.; Masters, J.N.; Beattie, M.S. Apoptosis and delayed degeneration after spinal cord injury in rats and monkeys. Nat. Med. 1997, 3, 73-76. [CrossRef]

81. Totoiu, M.O.; Keirstead, H.S. Spinal cord injury is accompanied by chronic progressive demyelination. J. Comp. Neurol. 2005, 486, 373-383. [CrossRef] [PubMed]

82. Kakulas, B.A. Neuropathology: The foundation for new treatments in spinal cord injury. Spinal Cord 2004, 42, 549-563. [CrossRef] [PubMed]

83. Guest, J.D.; Hiester, E.D.; Bunge, R.P. Demyelination and Schwann cell responses adjacent to injury epicenter cavities following chronic human spinal cord injury. Exp. Neurol. 2005, 192, 384-393. [CrossRef]

84. Emery, E.; Aldana, P.; Bunge, M.B.; Puckett, W.; Srinivasan, A.; Keane, R.W.; Bethea, J.; Levi, A.D. Apoptosis after traumatic human spinal cord injury. J. Neurosurg. 1998, 89, 911-920. [CrossRef]

85. Assinck, P.; Duncan, G.J.; Plemel, J.R.; Lee, M.J.; Stratton, J.A.; Manesh, S.B.; Liu, J.; Ramer, L.M.; Kang, S.H.; Bergles, D.E.; et al. Myelinogenic Plasticity of Oligodendrocyte Precursor Cells following Spinal Cord Contusion Injury. J. Neurosci. 2017, 37, 8635-8654. [CrossRef] [PubMed]

86. Hesp, Z.C.; Goldstein, E.Z.; Miranda, C.J.; Kaspar, B.K.; McTigue, D.M. Chronic oligodendrogenesis and remyelination after spinal cord injury in mice and rats. J. Neurosci. 2015, 35, 1274-1290. [CrossRef]

87. Lu, P.; Yang, H.; Jones, L.L.; Filbin, M.T.; Tuszynski, M.H. Combinatorial therapy with neurotrophins and cAMP promotes axonal regeneration beyond sites of spinal cord injury. J. Neurosci. 2004, 24, 6402-6409. [CrossRef]

88. Filous, A.R.; Silver, J. "Targeting astrocytes in CNS injury and disease: A translational research approach". Prog. Neurobiol. 2016, 144, 173-187. [CrossRef]

89. Burda, J.E.; Sofroniew, M.V. Reactive gliosis and the multicellular response to CNS damage and disease. Neuron 2014, 81, 229-248. [CrossRef]

90. Goritz, C.; Dias, D.O.; Tomilin, N.; Barbacid, M.; Shupliakov, O.; Frisen, J. A pericyte origin of spinal cord scar tissue. Science 2011, 333, 238-242. [CrossRef]

91. Zhu, Y.; Soderblom, C.; Krishnan, V.; Ashbaugh, J.; Bethea, J.R.; Lee, J.K. Hematogenous macrophage depletion reduces the fibrotic scar and increases axonal growth after spinal cord injury. Neurobiol. Dis. 2015, 74, 114-125. [CrossRef]

92. Adams, K.L.; Gallo, V. The diversity and disparity of the glial scar. Nat. Neurosci. 2018, 21, 9-15. [CrossRef] [PubMed]

93. Windle, W.F.; Clemente, C.D.; Chambers, W.W. Inhibition of formation of a glial barrier as a means of permitting a peripheral nerve to grow into the brain. J. Comp. Neurol. 1952, 96, 359-369. [CrossRef]

94. Weidner, N.; Ner, A.; Salimi, N.; Tuszynski, M.H. Spontaneous corticospinal axonal plasticity and functional recovery after adult central nervous system injury. Proc. Natl. Acad. Sci. USA 2001, 98, 3513-3518. [CrossRef]

95. Murray, K.C.; Nakae, A.; Stephens, M.J.; Rank, M.; D'Amico, J.; Harvey, P.J.; Li, X.; Harris, R.L.; Ballou, E.W.; Anelli, R.; et al. Recovery of motoneuron and locomotor function after spinal cord injury depends on constitutive activity in 5-HT2C receptors. Nat. Med. 2010, 16, 694-700. [CrossRef]

96. Bareyre, F.M.; Kerschensteiner, M.; Raineteau, O.; Mettenleiter, T.C.; Weinmann, O.; Schwab, M.E. The injured spinal cord spontaneously forms a new intraspinal circuit in adult rats. Nat. Neurosci. 2004, 7, 269-277. [CrossRef] [PubMed] 
97. Courtine, G.; Song, B.; Roy, R.R.; Zhong, H.; Herrmann, J.E.; Ao, Y.; Qi, J.; Edgerton, V.R.; Sofroniew, M.V. Recovery of supraspinal control of stepping via indirect propriospinal relay connections after spinal cord injury. Nat. Med. 2008, 14, 69-74. [CrossRef] [PubMed]

98. Takeoka, A.; Vollenweider, I.; Courtine, G.; Arber, S. Muscle spindle feedback directs locomotor recovery and circuit reorganization after spinal cord injury. Cell 2014, 159, 1626-1639. [CrossRef]

99. Raineteau, O.; Schwab, M.E. Plasticity of motor systems after incomplete spinal cord injury. Nat. Rev. Neurosci. 2001, 2, 263-273. [CrossRef]

100. Rosenzweig, E.S.; Courtine, G.; Jindrich, D.L.; Brock, J.H.; Ferguson, A.R.; Strand, S.C.; Nout, Y.S.; Roy, R.R.; Miller, D.M.; Beattie, M.S.; et al. Extensive spontaneous plasticity of corticospinal projections after primate spinal cord injury. Nat. Neurosci. 2010, 13, 1505-1510. [CrossRef]

101. Friedli, L.; Rosenzweig, E.S.; Barraud, Q.; Schubert, M.; Dominici, N.; Awai, L.; Nielson, J.L.; Musienko, P.; Nout-Lomas, Y.; Zhong, H.; et al. Pronounced species divergence in corticospinal tract reorganization and functional recovery after lateralized spinal cord injury favors primates. Sci. Transl. Med. 2015, 7, 302ra134. [CrossRef] [PubMed]

102. Ballermann, M.; Fouad, K. Spontaneous locomotor recovery in spinal cord injured rats is accompanied by anatomical plasticity of reticulospinal fibers. Eur. J. Neurosci. 2006, 23, 1988-1996. [CrossRef]

103. Belhaj-Saif, A.; Cheney, P.D. Plasticity in the distribution of the red nucleus output to forearm muscles after unilateral lesions of the pyramidal tract. J. Neurophysiol. 2000, 83, 3147-3153. [CrossRef]

104. Mullner, A.; Gonzenbach, R.R.; Weinmann, O.; Schnell, L.; Liebscher, T.; Schwab, M.E. Lamina-specific restoration of serotonergic projections after Nogo-A antibody treatment of spinal cord injury in rats. Eur. J. Neurosci. 2008, 27, 326-333. [CrossRef] [PubMed]

105. Deng, L.; Ruan, Y.; Chen, C.; Frye, C.C.; Xiong, W.; Jin, X.; Jones, K.; Sengelaub, D.; Xu, X.M. Characterization of dendritic morphology and neurotransmitter phenotype of thoracic descending propriospinal neurons after complete spinal cord transection and GDNF treatment. Exp. Neurol. 2016, 277, 103-114. [CrossRef]

106. Sekhon, L.H.; Fehlings, M.G. Epidemiology, demographics, and pathophysiology of acute spinal cord injury. Spine 2001, 26 (Suppl. 24), S2-S12. [CrossRef]

107. Sofroniew, M.V. Dissecting spinal cord regeneration. Nature 2018, 557, 343-350. [CrossRef]

108. O'Shea, T.M.; Burda, J.E.; Sofroniew, M.V. Cell biology of spinal cord injury and repair. J. Clin. Invest. 2017, 127, 3259-3270. [CrossRef]

109. Cantinieaux, D.; Quertainmont, R.; Blacher, S.; Rossi, L.; Wanet, T.; Noel, A.; Brook, G.; Schoenen, J.; Franzen, R. Conditioned medium from bone marrow-derived mesenchymal stem cells improves recovery after spinal cord injury in rats: An original strategy to avoid cell transplantation. PLoS ONE 2013, 8, e69515. [CrossRef] [PubMed]

110. Cheng, Z.; Zhu, W.; Cao, K.; Wu, F.; Li, J.; Wang, G.; Li, H.; Lu, M.; Ren, Y.; He, X. Anti-Inflammatory Mechanism of Neural Stem Cell Transplantation in Spinal Cord Injury. Int. J. Mol. Sci. 2016, 17, 1380. [CrossRef] [PubMed]

111. Nakajima, H.; Uchida, K.; Guerrero, A.R.; Watanabe, S.; Sugita, D.; Takeura, N.; Yoshida, A.; Long, G.; Wright, K.T.; Johnson, W.E.; et al. Transplantation of mesenchymal stem cells promotes an alternative pathway of macrophage activation and functional recovery after spinal cord injury. J. Neurotrauma 2012, 29, 1614-1625. [CrossRef]

112. Griffin, J.M.; Bradke, F. Therapeutic repair for spinal cord injury: Combinatory approaches to address a multifaceted problem. EMBO Mol. Med. 2020, 12, e11505. [CrossRef] [PubMed]

113. Anderson, M.A.; O'Shea, T.M.; Burda, J.E.; Ao, Y.; Barlatey, S.L.; Bernstein, A.M.; Kim, J.H.; James, N.D.; Rogers, A.; Kato, B.; et al. Required growth facilitators propel axon regeneration across complete spinal cord injury. Nature 2018, 561, 396-400. [CrossRef] [PubMed]

114. Edgerton, V.R.; Tillakaratne, N.J.; Bigbee, A.J.; de Leon, R.D.; Roy, R.R. Plasticity of the spinal neural circuitry after injury. Annu. Rev. Neurosci. 2004, 27, 145-167. [CrossRef]

115. Lovett-Barr, M.R.; Satriotomo, I.; Muir, G.D.; Wilkerson, J.E.; Hoffman, M.S.; Vinit, S.; Mitchell, G.S. Repetitive intermittent hypoxia induces respiratory and somatic motor recovery after chronic cervical spinal injury. J. Neurosci. 2012, 32, 3591-3600. [CrossRef] [PubMed]

116. Garraway, S.M.; Huie, J.R. Spinal Plasticity and Behavior: BDNF-Induced Neuromodulation in Uninjured and Injured Spinal Cord. Neural Plast. 2016, 2016, 9857201. [CrossRef]

117. Mendell, L.M.; Munson, J.B.; Arvanian, V.L. Neurotrophins and synaptic plasticity in the mammalian spinal cord. J. Physiol. 2001, 533, 91-97. [CrossRef]

118. Poo, M.M. Neurotrophins as synaptic modulators. Nat. Rev. Neurosci. 2001, 2, 24-32. [CrossRef]

119. Matsubayashi, K.; Nagoshi, N.; Komaki, Y.; Kojima, K.; Shinozaki, M.; Tsuji, O.; Iwanami, A.; Ishihara, R.; Takata, N.; Matsumoto, M.; et al. Assessing cortical plasticity after spinal cord injury by using resting-state functional magnetic resonance imaging in awake adult mice. Sci. Rep. 2018, 8, 14406. [CrossRef] [PubMed]

120. Hilton, B.J.; Anenberg, E.; Harrison, T.C.; Boyd, J.D.; Murphy, T.H.; Tetzlaff, W. Re-Establishment of Cortical Motor Output Maps and Spontaneous Functional Recovery via Spared Dorsolaterally Projecting Corticospinal Neurons after Dorsal Column Spinal Cord Injury in Adult Mice. J. Neurosci. 2016, 36, 4080-4092. [CrossRef]

121. Hollis, E.R., 2nd; Ishiko, N.; Yu, T.; Lu, C.C.; Haimovich, A.; Tolentino, K.; Richman, A.; Tury, A.; Wang, S.H.; Pessian, M.; et al. Ryk controls remapping of motor cortex during functional recovery after spinal cord injury. Nat. Neurosci. 2016, 19, 697-705. [CrossRef] 
122. van den Brand, R.; Heutschi, J.; Barraud, Q.; DiGiovanna, J.; Bartholdi, K.; Huerlimann, M.; Friedli, L.; Vollenweider, I.; Moraud, E.M.; Duis, S.; et al. Restoring voluntary control of locomotion after paralyzing spinal cord injury. Science 2012, 336, $1182-1185$. [CrossRef]

123. Asboth, L.; Friedli, L.; Beauparlant, J.; Martinez-Gonzalez, C.; Anil, S.; Rey, E.; Baud, L.; Pidpruzhnykova, G.; Anderson, M.A.; Shkorbatova, P.; et al. Cortico-reticulo-spinal circuit reorganization enables functional recovery after severe spinal cord contusion. Nat. Neurosci. 2018, 21, 576-588. [CrossRef]

124. Kanagal, S.G.; Muir, G.D. Task-dependent compensation after pyramidal tract and dorsolateral spinal lesions in rats. Exp. Neurol. 2009, 216, 193-206. [CrossRef]

125. Lin, C.L.; Heron, P.; Hamann, S.R.; Smith, G.M. Functional distinction between NGF-mediated plasticity and regeneration of nociceptive axons within the spinal cord. Neuroscience 2014, 272, 76-87. [CrossRef] [PubMed]

126. Lee, Y.; Morrison, B.M.; Li, Y.; Lengacher, S.; Farah, M.H.; Hoffman, P.N.; Liu, Y.; Tsingalia, A.; Jin, L.; Zhang, P.W.; et al. Oligodendroglia metabolically support axons and contribute to neurodegeneration. Nature 2012, 487, 443-448. [CrossRef]

127. Funfschilling, U.; Supplie, L.M.; Mahad, D.; Boretius, S.; Saab, A.S.; Edgar, J.; Brinkmann, B.G.; Kassmann, C.M.; Tzvetanova, I.D.; Mobius, W.; et al. Glycolytic oligodendrocytes maintain myelin and long-term axonal integrity. Nature 2012, 485, 517-521. [CrossRef] [PubMed]

128. Blight, A.R.; Young, W. Central axons in injured cat spinal cord recover electrophysiological function following remyelination by Schwann cells. J. Neurol. Sci. 1989, 91, 15-34. [CrossRef]

129. Smith, K.J.; Blakemore, W.F.; McDonald, W.I. Central remyelination restores secure conduction. Nature 1979, $280,395-396$. [CrossRef]

130. Yasuda, A.; Tsuji, O.; Shibata, S.; Nori, S.; Takano, M.; Kobayashi, Y.; Takahashi, Y.; Fujiyoshi, K.; Hara, C.M.; Miyawaki, A.; et al. Significance of remyelination by neural stem/progenitor cells transplanted into the injured spinal cord. Stem Cells 2011, 29, 1983-1994. [CrossRef] [PubMed]

131. Sidoryk-Wegrzynowicz, M.; Struzynska, L. Astroglial and Microglial Purinergic P2X7 Receptor as a Major Contributor to Neuroinflammation during the Course of Multiple Sclerosis. Int. J. Mol. Sci. 2021, 22, 8404. [CrossRef] [PubMed]

132. Sen, M.K.; Almuslehi, M.S.M.; Shortland, P.J.; Mahns, D.A.; Coorssen, J.R. Proteomics of Multiple Sclerosis: Inherent Issues in Defining the Pathoetiology and Identifying (Early) Biomarkers. Int. J. Mol. Sci. 2021, 22, 7377. [CrossRef]

133. Koike, H.; Katsuno, M. Macrophages and Autoantibodies in Demyelinating Diseases. Cells 2021, 10, 844. [CrossRef]

134. Lucchinetti, C.; Bruck, W.; Parisi, J.; Scheithauer, B.; Rodriguez, M.; Lassmann, H. Heterogeneity of multiple sclerosis lesions: Implications for the pathogenesis of demyelination. Ann. Neurol. 2000, 47, 707-717. [CrossRef]

135. Schultz, V.; van der Meer, F.; Wrzos, C.; Scheidt, U.; Bahn, E.; Stadelmann, C.; Bruck, W.; Junker, A. Acutely damaged axons are remyelinated in multiple sclerosis and experimental models of demyelination. Glia 2017, 65, 1350-1360. [CrossRef] [PubMed]

136. Muramatsu, R.; Kuroda, M.; Matoba, K.; Lin, H.; Takahashi, C.; Koyama, Y.; Yamashita, T. Prostacyclin prevents pericyte loss and demyelination induced by lysophosphatidylcholine in the central nervous system. J. Biol. Chem. 2015, 290, 11515-11525. [CrossRef]

137. Kamata, Y.; Isoda, M.; Sanosaka, T.; Shibata, R.; Ito, S.; Okubo, T.; Shinozaki, M.; Inoue, M.; Koya, I.; Shibata, S.; et al. A robust culture system to generate neural progenitors with gliogenic competence from clinically relevant induced pluripotent stem cells for treatment of spinal cord injury. Stem Cells Transl. Med. 2021, 10, 398-413. [CrossRef]

138. Duncan, G.J.; Manesh, S.B.; Hilton, B.J.; Assinck, P.; Liu, J.; Moulson, A.; Plemel, J.R.; Tetzlaff, W. Locomotor recovery following contusive spinal cord injury does not require oligodendrocyte remyelination. Nat. Commun. 2018, 9, 3066. [CrossRef] [PubMed]

139. Bonner, J.F.; Connors, T.M.; Silverman, W.F.; Kowalski, D.P.; Lemay, M.A.; Fischer, I. Grafted neural progenitors integrate and restore synaptic connectivity across the injured spinal cord. J. Neurosci. 2011, 31, 4675-4686. [CrossRef]

140. Abematsu, M.; Tsujimura, K.; Yamano, M.; Saito, M.; Kohno, K.; Kohyama, J.; Namihira, M.; Komiya, S.; Nakashima, K. Neurons derived from transplanted neural stem cells restore disrupted neuronal circuitry in a mouse model of spinal cord injury. J. Clin. Invest. 2010, 120, 3255-3266. [CrossRef]

141. Ladewig, J.; Koch, P.; Brustle, O. Auto-attraction of neural precursors and their neuronal progeny impairs neuronal migration. Nat. Neurosci. 2014, 17, 24-26. [CrossRef] [PubMed]

142. Wahl, A.S.; Omlor, W.; Rubio, J.C.; Chen, J.L.; Zheng, H.; Schroter, A.; Gullo, M.; Weinmann, O.; Kobayashi, K.; Helmchen, F.; et al. Neuronal repair. Asynchronous therapy restores motor control by rewiring of the rat corticospinal tract after stroke. Science 2014, 344, 1250-1255. [CrossRef]

143. Doulames, V.M.; Plant, G.W. Induced Pluripotent Stem Cell Therapies for Cervical Spinal Cord Injury. Int. J. Mol. Sci. 2016, 17, 530. [CrossRef] [PubMed]

144. Martinez, M.; Brezun, J.M.; Bonnier, L.; Xerri, C. A new rating scale for open-field evaluation of behavioral recovery after cervical spinal cord injury in rats. J. Neurotrauma 2009, 26, 1043-1053. [CrossRef] [PubMed]

145. Dvorak, M.F.; Noonan, V.K.; Fallah, N.; Fisher, C.G.; Rivers, C.S.; Ahn, H.; Tsai, E.C.; Linassi, A.G.; Christie, S.D.; Attabib, N.; et al. Minimizing errors in acute traumatic spinal cord injury trials by acknowledging the heterogeneity of spinal cord anatomy and injury severity: An observational Canadian cohort analysis. J. Neurotrauma 2014, 31, 1540-1547. [CrossRef]

146. Consortium for Spinal Cord Medicine. Outcomes following traumatic spinal cord injury: Clinical practice guidelines for health-care professionals. J Spinal Cord Med. 2000, 23, 289-316. [CrossRef] 
147. Honmou, O.; Yamashita, T.; Morita, T.; Oshigiri, T.; Hirota, R.; Iyama, S.; Kato, J.; Sasaki, Y.; Ishiai, S.; Ito, Y.M.; et al. Intravenous infusion of auto serum-expanded autologous mesenchymal stem cells in spinal cord injury patients: 13 case series. Clin. Neurol. Neurosurg. 2021, 203, 106565. [CrossRef]

148. Tashiro, S.; Nishimura, S.; Iwai, H.; Sugai, K.; Zhang, L.; Shinozaki, M.; Iwanami, A.; Toyama, Y.; Liu, M.; Okano, H.; et al. Functional Recovery from Neural Stem/Progenitor Cell Transplantation Combined with Treadmill Training in Mice with Chronic Spinal Cord Injury. Sci. Rep. 2016, 6, 30898. [CrossRef]

149. Vuckovic, A.; Altaleb, M.K.H.; Fraser, M.; McGeady, C.; Purcell, M. EEG Correlates of Self-Managed Neurofeedback Treatment of Central Neuropathic Pain in Chronic Spinal Cord Injury. Front. Neurosci. 2019, 13, 762. [CrossRef]

150. Hendricks, H.T.; Ijzerman, M.A.; de Kroon, J.R.; in 't Groen, F.A.; Zilvold, G. Functional electrical stimulation by means of the 'Ness Handmaster Orthosis' in chronic stroke patients: An exploratory study. Clin. Rehabil. 2001, 15, 217-220. [CrossRef]

151. Wall, A.; Borg, J.; Palmcrantz, S. Clinical application of the Hybrid Assistive Limb (HAL) for gait training-a systematic review. Front. Syst. Neurosci. 2015, 9, 48. [CrossRef]

152. Tsuchimoto, S.; Shindo, K.; Hotta, F.; Hanakawa, T.; Liu, M.; Ushiba, J. Sensorimotor Connectivity after Motor Exercise with Neurofeedback in Post-Stroke Patients with Hemiplegia. Neuroscience 2019, 416, 109-125. [CrossRef]

153. Gerasimenko, Y.P.; Lu, D.C.; Modaber, M.; Zdunowski, S.; Gad, P.; Sayenko, D.G.; Morikawa, E.; Haakana, P.; Ferguson, A.R.; Roy, R.R.; et al. Noninvasive Reactivation of Motor Descending Control after Paralysis. J. Neurotrauma 2015, 32, 1968-1980. [CrossRef]

154. Wenger, N.; Moraud, E.M.; Gandar, J.; Musienko, P.; Capogrosso, M.; Baud, L.; Le Goff, C.G.; Barraud, Q.; Pavlova, N.; Dominici, N.; et al. Spatiotemporal neuromodulation therapies engaging muscle synergies improve motor control after spinal cord injury. Nat. Med. 2016, 22, 138-145. [CrossRef]

155. Grahn, P.J.; Lavrov, I.A.; Sayenko, D.G.; Van Straaten, M.G.; Gill, M.L.; Strommen, J.A.; Calvert, J.S.; Drubach, D.I.; Beck, L.A.; Linde, M.B.; et al. Enabling Task-Specific Volitional Motor Functions via Spinal Cord Neuromodulation in a Human with Paraplegia. Mayo Clin. Proc. 2017, 92, 544-554. [CrossRef] [PubMed]

156. Herman, R.; He, J.; D'Luzansky, S.; Willis, W.; Dilli, S. Spinal cord stimulation facilitates functional walking in a chronic, incomplete spinal cord injured. Spinal Cord 2002, 40, 65-68. [CrossRef]

157. Danner, S.M.; Hofstoetter, U.S.; Freundl, B.; Binder, H.; Mayr, W.; Rattay, F.; Minassian, K. Human spinal locomotor control is based on flexibly organized burst generators. Brain 2015, 138, 577-588. [CrossRef] [PubMed]

158. Wagner, F.B.; Mignardot, J.B.; Le Goff-Mignardot, C.G.; Demesmaeker, R.; Komi, S.; Capogrosso, M.; Rowald, A.; Seanez, I.; Caban, M.; Pirondini, E.; et al. Targeted neurotechnology restores walking in humans with spinal cord injury. Nature 2018, 563, 65-71. [CrossRef] [PubMed]

159. Gill, M.L.; Grahn, P.J.; Calvert, J.S.; Linde, M.B.; Lavrov, I.A.; Strommen, J.A.; Beck, L.A.; Sayenko, D.G.; Van Straaten, M.G.; Drubach, D.I.; et al. Neuromodulation of lumbosacral spinal networks enables independent stepping after complete paraplegia. Nat. Med. 2018, 24, 1677-1682. [CrossRef]

160. Minev, I.R.; Musienko, P.; Hirsch, A.; Barraud, Q.; Wenger, N.; Moraud, E.M.; Gandar, J.; Capogrosso, M.; Milekovic, T.; Asboth, L.; et al. Biomaterials. Electronic dura mater for long-term multimodal neural interfaces. Science 2015, 347, 159-163. [CrossRef]

161. Holinski, B.J.; Mazurek, K.A.; Everaert, D.G.; Toossi, A.; Lucas-Osma, A.M.; Troyk, P.; Etienne-Cummings, R.; Stein, R.B.; Mushahwar, V.K. Intraspinal microstimulation produces over-ground walking in anesthetized cats. J. Neural Eng. 2016, $13,056016$. [CrossRef]

162. Zimmermann, J.B.; Seki, K.; Jackson, A. Reanimating the arm and hand with intraspinal microstimulation. J. Neural Eng. 2011, 8, 054001. [CrossRef]

163. Kasten, M.R.; Sunshine, M.D.; Secrist, E.S.; Horner, P.J.; Moritz, C.T. Therapeutic intraspinal microstimulation improves forelimb function after cervical contusion injury. J. Neural Eng. 2013, 10, 044001. [CrossRef]

164. Angeli, C.A.; Edgerton, V.R.; Gerasimenko, Y.P.; Harkema, S.J. Altering spinal cord excitability enables voluntary movements after chronic complete paralysis in humans. Brain 2014, 137, 1394-1409. [CrossRef] [PubMed]

165. Lu, D.C.; Edgerton, V.R.; Modaber, M.; AuYong, N.; Morikawa, E.; Zdunowski, S.; Sarino, M.E.; Sarrafzadeh, M.; Nuwer, M.R.; Roy, R.R.; et al. Engaging Cervical Spinal Cord Networks to Reenable Volitional Control of Hand Function in Tetraplegic Patients. Neurorehabil. Neural Repair 2016, 30, 951-962. [CrossRef] [PubMed]

166. Phillips, A.A.; Squair, J.W.; Sayenko, D.G.; Edgerton, V.R.; Gerasimenko, Y.; Krassioukov, A.V. An Autonomic Neuroprosthesis: Noninvasive Electrical Spinal Cord Stimulation Restores Autonomic Cardiovascular Function in Individuals with Spinal Cord Injury. J. Neurotrauma 2018, 35, 446-451. [CrossRef] [PubMed]

167. Hachmann, J.T.; Grahn, P.J.; Calvert, J.S.; Drubach, D.I.; Lee, K.H.; Lavrov, I.A. Electrical Neuromodulation of the Respiratory System After Spinal Cord Injury. Mayo Clin. Proc. 2017, 92, 1401-1414. [CrossRef] [PubMed]

168. Carmel, J.B.; Martin, J.H. Motor cortex electrical stimulation augments sprouting of the corticospinal tract and promotes recovery of motor function. Front. Integr. Neurosci. 2014, 8, 51. [CrossRef]

169. Moraud, E.M.; Capogrosso, M.; Formento, E.; Wenger, N.; DiGiovanna, J.; Courtine, G.; Micera, S. Mechanisms Underlying the Neuromodulation of Spinal Circuits for Correcting Gait and Balance Deficits after Spinal Cord Injury. Neuron 2016, 89, 814-828. [CrossRef]

170. Capogrosso, M.; Wenger, N.; Raspopovic, S.; Musienko, P.; Beauparlant, J.; Bassi Luciani, L.; Courtine, G.; Micera, S. A computational model for epidural electrical stimulation of spinal sensorimotor circuits. J. Neurosci. 2013, 33, 19326-19340. [CrossRef] 